\title{
Impact of forest harvesting on water quality and fluorescence characteristics of dissolved organic matter in eastern Canadian Boreal Shield lakes in summer
}

\author{
P. Glaz ${ }^{1}$, J.-P. Gagné ${ }^{2}$, P. Archambault ${ }^{2}$, P. Sirois ${ }^{3}$, and C. Nozais ${ }^{1}$ \\ ${ }^{1}$ Département de biologie, chimie et géographie, Université du Québec à Rimouski, Rimouski (QC), Canada \\ ${ }^{2}$ Institut des sciences de la mer de Rimouski, Université du Québec à Rimouski, Rimouski (QC), Canada \\ ${ }^{3}$ Chaire de recherche sur les espèces aquatiques exploitées, Laboratoire des sciences aquatiques, Département \\ des sciences fondamentales, Université du Québec à Chicoutimi, Chicoutimi (QC), Canada
}

Correspondence to: P. Glaz (patricia_glaz@uqar.ca)

Received: 29 May 2015 - Published in Biogeosciences Discuss.: 23 June 2015

Revised: 24 November 2015 - Accepted: 24 November 2015 - Published: 7 December 2015

\begin{abstract}
Forestry activities in the Canadian Boreal region have increased in the last decades, raising concerns about their potential impact on aquatic ecosystems. Water quality and fluorescence characteristics of dissolved organic matter (DOM) were measured over a 3-year period in eight eastern Boreal Shield lakes: four lakes were studied before, 1 and 2 years after forest harvesting (perturbed lakes) and compared with four undisturbed reference lakes (unperturbed lakes) sampled at the same time. ANOVAs showed a significant increase in total phosphorus (TP) in perturbed lakes when the three sampling dates were considered and in DOC concentrations when considering 1 year before and 1 year after the perturbation only. At 1 year post-clear cutting DOC concentrations were about $15 \%$ greater in the perturbed lakes at $\sim 15 \mathrm{mgC} \mathrm{L}^{-1}$ compared to $12.5 \mathrm{mgC} \mathrm{L}^{-1}$ in the unperturbed lakes. In contrast, absorbance and fluorescence measurements showed that all metrics remained within narrow ranges compared to the range observed in natural waters, indicating that forest harvesting did not affect the nature of DOM characterized with spectroscopic techniques. These results confirm an impact of forestry activities 1 year after the perturbation. However, this effect seems to be mitigated 2 years after, indicating that the system shows high resilience and may be able to return to its original condition in terms of water quality parameters assessed in this study.
\end{abstract}

\section{Introduction}

Boreal forests, which contain large areas of wetlands and over 1.5 million lakes, are an ecological, economic and cultural source of wealth in Canada (NRCan, 2005; Kreutzweiser et al., 2008). These lakes receive allochthonous inputs of dissolved and particulate matter from natural sources and anthropic activities (Schindler et al., 1992). Forestry activities in the Canadian Boreal region have increased in the last decades, raising concerns about their potential impact on natural biogeochemical processes in soils and the export pathways that deliver dissolved nutrients and organic matter to aquatic ecosystems. After logging, the export of dissolved nutrients to aquatic ecosystems increases, which is primarily related to a higher microbial activity in upper soil layers and the forest floor (Bormann and Likens, 1994; Kreutzweiser et al., 2008). This microbial activity converts nutrients from non-mobile to mobile forms, which are exported to receiving waters (Buttle et al., 2005), affecting loads of nutrients and organic compounds in lakes and rivers. Because forestry is the most extensive industry in much of the boreal region, the potential influence of logging on carbon reservoirs and water quality could be substantial. Therefore, there is a need to understand the long-term effects of forest harvesting on water quality, as well as its short transient repercussions.

Studies on the effects of logging activities on aquatic ecosystems in the boreal region have mostly been oriented to lotic systems (e.g., Smith et al., 2003; Laudon et al., 2009; 
Löfgren et al., 2009). In contrast, responses of lentic systems to logging activities in the boreal region have not been as extensively studied. Logging activities such as clear-cutting may produce significant disturbances to forest watersheds altering biogeochemical processes in soils by modifying forest vegetation cover and plant community, soils conditions, moisture and temperature regimes (Schelker et al., 2013b), soil microbial activity, water mobility and losses of leaching matter to receiving waters (Kreutzweiser et al., 2008). Increases in the watershed export of suspended solids, nutrients and dissolved organic carbon (DOC) were observed after 1 to 3 years following trees harvesting (Rask et al., 1998; Carignan et al., 2000; Winkler et al., 2009). DOC is one of the most central biogeochemical features of boreal surface waters because it affects the food web structure of surface waters in lakes (Findlay and Sinsabaugh, 2003) and it acts as a microbial substrate (Berggren et al., 2007). DOC has been intensively investigated in environmental research because of its significant role in various biogeochemical and ecological processes (Findlay and Sinsabaugh, 2003; Birdwell and Engel 2010). However, most of the short-term impact studies of catchment harvesting on lakes, with the exception of Winkler et al. (2009), did not measure the system before and after the perturbation in lakes that were not logged (i.e., unperturbed lakes), thereby changes due to logging cannot be separated from natural variability.

Quantitative and qualitative information about the source, composition and reactivity of the DOC present in an ecosystem at natural abundance concentration can be obtained by spectroscopic techniques (Coble, 1996, 2007; Deflandre and Gagné, 2001; Weishaar et al., 2003; Hudson et al., 2007; Fellman et al., 2010). UV-VIS spectroscopy allows characterization of chromophoric dissolved organic matter (CDOM) while the fluorescence spectra of natural waters show characteristic maxima of few fluorophores that may vary between environments (Coble, 1996, 2007; Stedmon et al., 2003). Variations in the maximum excitation or emission wavelength can also provide information relating to structure, conformation and heterogeneity of DOM as observed by Mobeb et al. (1996) for humic substances, an important class of molecules found in natural water (Tremblay and Gagné, 2009). Moreover, fluorophores intensities can be used to calculate ratios to track biogeochemical processes. For instance, differences in the chemical make-up of the DOM pool can be linked to changes in DOM reactivity and may be used to infer DOM sources (Jaffé et al., 2008; McKnight et al., 2001). Thus, fluorescence spectra provide data that can be used to infer the relative contributions of autochthonous and allochthonous organic matter in natural waters (Parlanti et al., 2000; McKnight et al., 2001; Huguet et al., 2009; Fellman et al., 2010). As forestry activities can increase the export of nutrients, suspended solids and DOC into lakes (Rask et al., 1998; Carignan et al., 2000; Kreutzweiser et al., 2008), and therefore, of allochthonous material, fluorescence measurements may be an appropriate tool to assess logging impact on water quality in watersheds. In a recent study, Kelton et al. (2007) used fluorescence measurements to compare characteristics of DOM from boreal, agricultural and urban sites. They observed that DOM from different landscapes could be distinguished by fluorescence spectroscopy.

While the temporal variability and long-term lake response is of interest, our study was designed to analyze the shortterm impact of forestry activities on water quality, and on UV-VIS and fluorescence characteristics of DOC in eastern Canadian Boreal Shield lakes 1 year before and up to 2 years after the perturbation. Water quality and spectroscopic characteristics of four lakes were studied on one occasion before, and on two occasions after forestry operations (perturbed lakes, P) and compared with four undisturbed references lakes (unperturbed lakes, UP). More specifically, we tested the hypotheses that (1) nutrients and DOC would be greater in perturbed lakes than unperturbed lakes 1 and 2 years after the perturbation; (2) the UV-VIS and fluorescence signatures of DOM in perturbed lakes would indicate an increase in terrestrially derived (allochthonous) DOM after logging.

\section{Materials and methods}

\subsection{Study area}

This study was conducted in the province of Quebec on the forested Mistassibi River drainage basin $\left(50^{\circ} 07^{\prime} 30^{\prime} \mathrm{N}\right.$, $71^{\circ} 35^{\prime} 59^{\prime} \mathrm{W}$ ) located on the Boreal Shield (Fig. 1). The study area is characterized by old growth forest mainly dominated by mature black spruces (Picea mariana) exploited by the forest industry. The soil layer over the rock is thin.

\subsection{Sampling}

Eight lakes, which are oligotrophic in this region (Winkler et al., 2009), with similar geomorphologic characteristics were selected for this study (Table 1). To evaluate the most direct impact of harvesting, headwater lakes were selected, except for UP1, UP3 and P3. Upstream lakes of UP1 and UP3 were unperturbed and for P3, the upstream lake was also unperturbed and very small in comparison with the nominal lake. These eight lakes have been unperturbed in 2008 at the beginning of this survey. In 2009 and 2010, four of these lakes were kept undisturbed (unperturbed lakes) and four other lakes (perturbed lakes) were harvested about $70 \%$ of lake catchment during autumn 2008 (Fig. 1, Table 1). All lakes were sampled once in July in 2008, 2009 and 2010. The experimental unit in this study was the lake. The forest was cut using the careful logging around advanced growth (CLAAG) strategy. Under this treatment, all trees equal to or greater than $10 \mathrm{~cm}$ diameter at breast height (d.b.h.) are harvested and smaller individuals are protected as future crop trees (Groot et al., 2005). A $20 \mathrm{~m}$ strip of standing forest was intentionally kept along lakes after harvesting activities. All 
Table 1. Characteristics of the eight studied Canadian Boreal Shield lakes (UP: unperturbed lakes; P: perturbed lakes). Dissolved oxygen (DO), $\mathrm{pH}$, conductivity, temperature, Secchi depth, total phosphorus (TP), dissolved inorganic phosphorous (DIP), dissolved inorganic nitrogen (DIN), chlorophyll $a$ (chl $a$ ) and dissolved organic carbon (DOC) are reported as means (SD) over the sampling stations on the photic zone before the perturbation (2008). Lake UP3 was not deep enough to sample Secchi depth.

\begin{tabular}{|c|c|c|c|c|c|c|c|c|}
\hline & UP1 & UP2 & UP3 & UP4 & $\mathrm{P} 1$ & $\mathrm{P} 2$ & P3 & P4 \\
\hline Latitude N & $50^{\circ} 25^{\prime} 44^{\prime \prime}$ & $50^{\circ} 29^{\prime} 22^{\prime \prime}$ & $50^{\circ} 23^{\prime} 13^{\prime \prime}$ & $50^{\circ} 28^{\prime} 34^{\prime \prime}$ & $50^{\circ} 30^{\prime} 9^{\prime \prime}$ & $50^{\circ} 31^{\prime} 25^{\prime \prime}$ & $50^{\circ} 30^{\prime} 40^{\prime \prime}$ & $50^{\circ} 28^{\prime} 11^{\prime \prime}$ \\
\hline Longitude W & $71^{\circ} 57^{\prime} 28^{\prime \prime}$ & $71^{\circ} 57^{\prime} 32^{\prime \prime}$ & $72^{\circ} 1^{\prime} 24^{\prime \prime}$ & $71^{\circ} 57^{\prime} 15^{\prime \prime}$ & $71^{\circ} 47^{\prime} 1^{\prime \prime}$ & $71^{\circ} 56^{\prime} 26^{\prime \prime}$ & $71^{\circ} 56^{\prime} 5^{\prime \prime}$ & $71^{\circ} 46^{\prime} 51^{\prime \prime}$ \\
\hline Lake area $\left(\mathrm{km}^{2}\right)$ & 0.17 & 0.17 & 0.06 & 0.03 & 0.29 & 0.09 & 0.28 & 0.04 \\
\hline Catchment area $\left(\mathrm{km}^{2}\right)$ & 0.92 & 2.80 & 0.59 & 0.20 & 2.89 & 1.76 & 2.42 & 0.34 \\
\hline Drainage area $\left(\mathrm{km}^{2}\right)$ & 0.75 & 2.63 & 0.52 & 0.17 & 2.61 & 1.67 & 2.14 & 0.29 \\
\hline Drainage ratio & 4.39 & 15.56 & 8.30 & 5.52 & 9.02 & 18.57 & 7.71 & 6.88 \\
\hline Harvested area (\% of catchment area) & - & - & - & - & 72.9 & 69.1 & 71.6 & 77.0 \\
\hline Mean annual lake residence time (year) & 0.10 & 0.01 & 0.005 & 0.03 & 0.16 & 0.04 & 0.15 & 0.05 \\
\hline Maximum depth (m) & 5.0 & 2.0 & 0.5 & 2 & 9 & 4.5 & 7.5 & 2 \\
\hline Secchi depth (m) & 1.25 & 1.50 & $\mathrm{n} / \mathrm{a}$ & 1.75 & 1.50 & 1.65 & 1.40 & 1.40 \\
\hline $\mathrm{DO}\left(\mathrm{mg} \mathrm{L}^{-1}\right)$ & $8.61(0.13)$ & $9.52(0.68)$ & $7.51(0.38)$ & $7.22(0.15)$ & $8.47(0.20)$ & $8.24(0.08)$ & $8.21(0.23)$ & $8.46(0.57)$ \\
\hline $\mathrm{pH}$ & $5.92(0.10)$ & $5.75(0.02)$ & $5.94(0.05)$ & $5.87(0.07)$ & $5.92(0.06)$ & $5.02(0.05)$ & $5.62(0.15)$ & $5.38(0.28)$ \\
\hline Conductivity $\left(\mu \mathrm{S} \mathrm{cm}^{-1}\right)$ & $11.93(0.64)$ & $12.50(0.05)$ & $19.00(0.54)$ & $9.40(0.15)$ & $13.40(0.00)$ & $11.92(0.12)$ & $12.65(0.14)$ & $14.67(0.45)$ \\
\hline Temperature $\left({ }^{\circ} \mathrm{C}\right)$ & $17.86(0.80)$ & $17.09(0.65)$ & $16.71(0.74)$ & $16.99(0.24)$ & $17.13(0.36)$ & $16.71(0.06)$ & $17.45(0.24)$ & $15.65(0.50)$ \\
\hline $\operatorname{DOC}\left(\mathrm{mg} \mathrm{L}^{-1}\right)$ & $10.78(0.57)$ & $12.06(0.58)$ & $12.56(1.01)$ & $12.33(0.48)$ & $11.91(0.73)$ & $9.82(0.40)$ & $8.98(0.43)$ & $13.73(1.04)$ \\
\hline $\operatorname{DIP}\left(\mu \mathrm{L} \mathrm{L}^{-1}\right)$ & $1.81(0.31)$ & $2.10(0.58)$ & $1.29(0.56)$ & $1.49(0.41)$ & $1.88(0.74)$ & $1.54(0.41)$ & $1.20(0.14)$ & $2.04(0.91)$ \\
\hline $\operatorname{DIN}\left(\mu \mathrm{gL}^{-1}\right)$ & $0.24(0.12)$ & $0.75(0.51)$ & $0.31(0.18)$ & $\mathrm{n} / \mathrm{a}$ & $0.60(0.12)$ & $\mathrm{n} / \mathrm{a}$ & $0.73(0.10)$ & $0.32(0.27)$ \\
\hline Chl $a\left(\mu \mathrm{g} \mathrm{L}^{-1}\right)$ & $0.43(0.06)$ & $0.39(0.06)$ & $0.62(0.20)$ & $0.36(0.05)$ & $0.98(0.21)$ & $0.55(0.06)$ & $0.68(0.16)$ & $0.49(0.07)$ \\
\hline $\mathrm{TP}\left(\mu \mathrm{g} \mathrm{L}^{-1}\right)$ & $5.05(0.26)$ & $4.95(0.52)$ & $5.77(0.50)$ & $5.13(1.01)$ & $5.09(0.70)$ & $4.69(0.47)$ & $5.26(0.70)$ & $4.65(0.55)$ \\
\hline
\end{tabular}

lakes have a drainage ratio higher than 4 , and perturbed lakes had a catchment area cut by 69-77\% (Table 1).

Mean annual lake residence time was calculated for each lake using the following equation:

Mean annual lake residence time

$$
=\frac{Z_{\mathrm{MD}} \times A_{\text {lake }}}{A_{\text {catchment }} \times P \times \text { runoff }} \text {, }
$$

where $Z_{\mathrm{MD}}$ is the mean depth, $A_{\text {lake }}$ is the lake area, $A_{\text {catchment }}$ is the catchment area, $P$ is the mean annual precipitation in this region (rainfall and snow) and runoff is the runoff coefficient. This coefficient assumes that the percentage of precipitation that becomes runoff is 0.5 for undisturbed lakes and 0.8 for harvested lakes in boreal forests (Bosch and Hewlett, 1982; Schelker et al., 2013a). Equation (1) is an approximation to calculate the mean annual lake residence time for each lake because for lakes, in absence of data, we assumed only precipitation and no infiltration or water uptake by tree roots, no loss of water by evaporation and evapotranspiration to the atmosphere or by groundwater recharge.

At each lake, five littoral stations were selected randomly and sampled from a vessel. Dissolved $\mathrm{O}_{2}, \mathrm{pH}$, conductivity and water temperature were measured in situ at each sampling station using a YSI 556 MPS probe. Water transparency was estimated at the deepest zone of the lake using a Secchi disc. Water samples were collected with a bottle at $0.5 \mathrm{~m}$ below the surface at each sampling station and filtered through $300 \mu \mathrm{m}$ to remove large zooplankton prior to the determination of physicochemical and biological variables. Samples for total phosphorus (TP), dissolved inorganic phospho- rus and nitrogen (DIP and DIN, respectively) and suspended matter filtered for chlorophyll $a(\mathrm{chl} a)$ measurements were kept frozen at $-20{ }^{\circ} \mathrm{C}$ until analysis. Freezing TP samples can change the concentration observed in some cases (Fellman et al., 2008). However, in this study it is assumed that freezing has no effect because SUVA measured for samples are low (see later). Samples for DOC, CDOM absorption and DOC fluorescence measurements were maintained at $4{ }^{\circ} \mathrm{C}$ until analysis after appropriate filtration treatments for each parameter.

\subsection{Water quality measurements}

TP was measured using the molybdenum blue method (Stainton et al., 1977) after autoclaving $50 \mathrm{~mL}$ samples with $0.5 \mathrm{~g}$ of potassium persulfate for $1 \mathrm{~h}$ at $120^{\circ} \mathrm{C}$. TP was afterwards assessed by using an AutoAnalyzer (AA3, Bran + Luebbe, German). DIP and DIN were determined using an AutoAnalyzer (AA3, Bran + Luebbe, German) after filtering water samples through a membrane filter $(0.2 \mu \mathrm{m}$ Sartorius $)$. For the determination of $\operatorname{chl} a$, water samples were filtered ( $200 \mathrm{~mL}$ or more) onto Whatman GF/F filters. Samples were extracted for $24 \mathrm{~h}$ in $90 \%$ acetone at $5^{\circ} \mathrm{C}$ in the dark without grinding. Chl $a$ was determined using the method of Welschmeyer et al. (1994). For DOC measurements, water samples were filtered through precombusted $\left(500^{\circ} \mathrm{C}, 5 \mathrm{~h}\right)$ Whatman GF/F filters. For the determination of DOC concentrations, the filtrates were collected in clean amber glass vials with Teflon-lined caps, and samples were acidified with $10 \mu \mathrm{L}$ of $25 \% v / v \mathrm{H}_{3} \mathrm{PO}_{4}$. The determination of DOC levels were made in NPOC mode with a TOC-5000A or a TOC$\mathrm{V}_{\mathrm{CPN}}$ analyzer (Shimadzu, Kyoto, Japan), following a proto- 


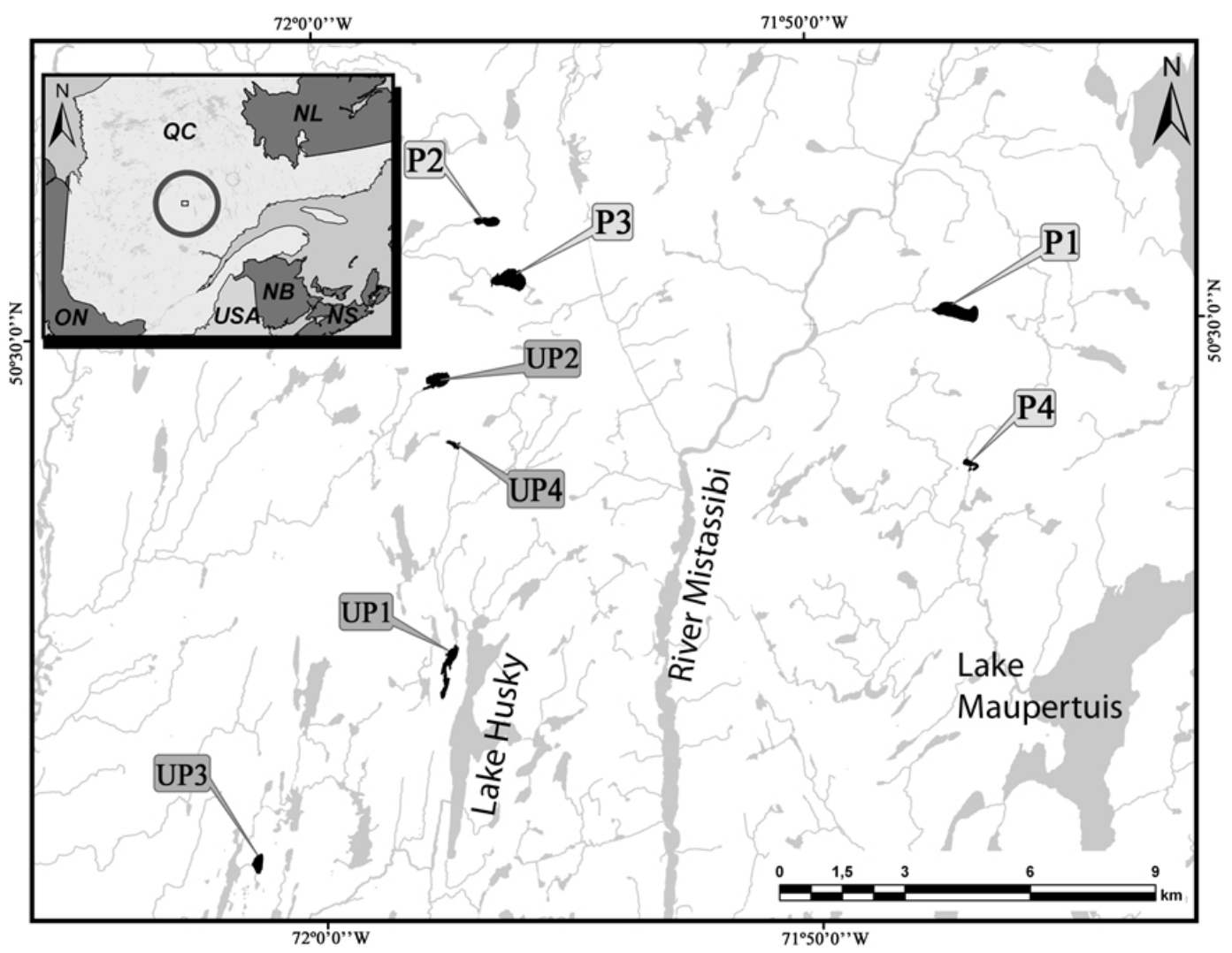

Figure 1. Location of the eight study lakes sampled in 2008, 2009 and 2010. UP, unperturbed lakes; P, perturbed lakes (harvested in 2009).

col similar to Whitehead et al. (2000). A calibration curve was used, with five concentrations of potassium hydrogen phthalate between 0 and $10 \mathrm{mg} \mathrm{C} \mathrm{L}^{-1}$ to determine the DOC content of samples. DOC reference standards available from the Hansell's Consensus Reference Materials (CRM) program were used to test the instruments. For boreal lakes with high DOC content, lowering the $\mathrm{pH}$ below 2, as done in the method, could change the solubility of DOM by driving precipitation or sorption of organic matter to the wall and cap of glass vials. However, the spectroscopic results obtained (see later) support the presence of fulvic instead of humic acids in lake waters. Since fulvic acids are soluble at any $\mathrm{pH}$, the acidification of the samples does not change the concentration of fulvic acids. We expect then that the acidification of the method did not change significantly the concentration of DOC in our samples. Samples for DOM fluorescence and CDOM absorption measurements were filtered through $0.2 \mu \mathrm{m}$ filters to remove bacteria and prevent decomposition of the DOC during storage. Samples were stored in dark to prevent photodegradation and photosynthesis.

\subsection{Absorption and fluorescence measurements}

CDOM absorption was determined for three stations in each lake with a Perkin Elmer Lambda 12 UV/VIS spectrophotometer, using a $5 \mathrm{~cm}$ pathlength quartz cuvette. Absorp- tion measurements were done over the range $200-600 \mathrm{~nm}$ with a spectral resolution of $1 \mathrm{~nm}$. Nanopure water was used as the blank to subtract the absorption due to pure water. Absorbance values were converted to absorption coefficient $a_{\mathrm{CDOM}}(\lambda)\left(\mathrm{m}^{-1}\right)$ using the following equation (Kirk, 1994):

$\mathrm{a}_{\mathrm{cDOM}}(\lambda)=\frac{2.303 \times A(\lambda)}{L}$,

where $A(\lambda)$ is the absorbance at wavelength $\lambda$ and $L$ is the pathlength of the cell used in the absorbance measurement in meters. In this study, $a_{\mathrm{CDOM}}$ at $\lambda=355 \mathrm{~nm}\left(a_{\mathrm{CDOM}}(355)\right)$ is used for data analysis.

Specific UV absorbance (SUVA) was calculated at $254 \mathrm{~nm}$. SUVA 254 is defined as the UV absorbance of a water sample at $254 \mathrm{~nm}$ divided by the DOC concentration measured in $\mathrm{mg} C$ per liter (Weishaar et al., 2003). SUVA is a measure of the absorbance by $\mathrm{mg}$ of carbon present in the sample. SUVA also allows an estimation of the aromaticity of the organic carbon present in the samples.

Finally, the spectral slope $(S)$ was calculated fitting an exponential equation between 305 and $265 \mathrm{~nm}$ (Galgani et al., 2011). Spectral slope is used to provide information on change in the composition and/or quality of CDOM, including the ratio of humic to fulvic acids (Galgani et al., 2011; Fichot and Benner, 2012). 
Table 2. Monthly (July), seasonal (May, June, July) and annual average of climatic variables during the 3 years of the study (2008, 2009 and 2010).

\begin{tabular}{lrrr}
\hline Variable (Average) & 2008 & 2009 & 2010 \\
\hline Monthly temperature $\left({ }^{\circ} \mathrm{C}\right)$ & 16.1 & 15.6 & 17.3 \\
Seasonal temperature $\left({ }^{\circ} \mathrm{C}\right)$ & 12.5 & 11.7 & 13.2 \\
Annual temperature $\left({ }^{\circ} \mathrm{C}\right)$ & -5.0 & -5.1 & -2.8 \\
Monthly precipitation $(\mathrm{mm})$ & 5.1 & 2.8 & 4.1 \\
Seasonal precipitation $(\mathrm{mm})$ & 46.1 & 44.2 & 44.8 \\
Annual snow depth $(\mathrm{mm})$ & 390 & 320 & 350 \\
\hline
\end{tabular}

Fluorescence measurements were made for the same three stations in each lake using a Fluoromax-4 HORIBA Jobin Yvon fluorometer with a $1 \mathrm{~cm}$ quartz cuvette, at $0.1 \mathrm{~s}$ integration time and with the standard R928P photomultiplier tube operating at 950 Volts. Prior to fluorescence analysis, the absorbance of each sample was measured with a UVVIS spectrophotometer (PerkinElmer Lambda 35). If the absorbance of the sample was higher than 0.05 AUFS, the sample was diluted to obtain absorbance in the range of $0.02-$ 0.03 AUFS. At this absorbance, the first and secondary inner filter effects are negligible (Lakowicz, 2006) and no correction has been done for the inner filter effects. Under these conditions, the fluorometer was never saturated. To obtain the three-dimensional excitation-emission fluorescence matrix (EEM), the instrument was operated in ratio mode to correct lamp fluctuation. Emission and excitation spectra were corrected for instrument bias as suggested by the manufacturer. The fluorescence EEM spectroscopy involved scanning and recording samples at sequential $5 \mathrm{~nm}$ increments of excitation wavelengths between 250 and $500 \mathrm{~nm}$. Emission wavelength increment was $2 \mathrm{~nm}$ between 250 and $600 \mathrm{~nm}$. The spectra were obtained by subtracting nanopure water blank spectra to eliminate water Raman scatter peaks. Each sample scan was then used to generate three-dimensional contour plots of fluorescence intensity as a function of excitation and emission wavelengths.

Our samples were characterized by two important fluorescent peaks. The first peak had an excitation maximum near 250-260 nm with an emission maximum near 380-480 nm. The second peak had an excitation maximum near 330 $350 \mathrm{~nm}$ and an emission maximum near $420-480 \mathrm{~nm}$. These fluorescence signals, called peaks $\mathrm{A}$ and $\mathrm{C}$, were assigned to humic-like substances by Coble (1996). No other salient peaks were observed in the fluorescence signal. From the intensity of peaks and other fluorescence signals, we calculated indices to quantify fluorescence properties of DOM. The ratio of fluorescence intensity of the two humic-like peaks (A / C) (Coble, 1996) was calculated for each sample. A change in the ratio of the intensity of these fluorophores reflects a change in the proportions of these fluorophores. A constant ratio A / C suggests a constant composition, a stable input or a stable environment. Fluorescence index (FI) was also calculated for each sample as the emission intensity at $470 \mathrm{~nm}$ divided by the emission intensity at $520 \mathrm{~nm}$ when the excitation energy was set at $370 \mathrm{~nm}$ (McKnight et al., 2001; Cory and McKnight, 2005). Two other indexes called the biological and/or autochthonous index (BIX) (Vacher, 2004; Huguet et al., 2009) and the humification index (HIX) (Zsolnay et al., 1999; Huguet et al., 2009) were calculated to assess the relative contribution of autochthonous DOM in samples. BIX was calculated from the ratio of emission intensities at $380 \mathrm{~nm}$ and $430 \mathrm{~nm}$ wavelengths when the excitation energy was set at $310 \mathrm{~nm}$. HIX was measured using the excitation wavelength $254 \mathrm{~nm}$ and calculated as the ratio of the area under emission spectra at $435-480 \mathrm{~nm}$ divided by the area under the $300-445 \mathrm{~nm}$ region.

\subsection{Data analyses}

Water characteristic variables (TP, DIP, DIN, chl $a$, DOC) and DOM spectroscopic parameters $\left(a_{\mathrm{CDOM}}(355)\right.$, fluorescence ratio A / C, FI, BIX, HIX, SUVA 254 and $S$ ) were compared using three-way partly nested analyses of variance (ANOVAs). Factors in the model were the following: treatment (fixed with two levels, unperturbed and perturbed), lake nested in treatment (random with four lakes per treatment), year (fixed with 3 years of sampling) and their interactions. Data were transformed when necessary to achieve normality and homogeneity of variance. The impact of forest harvesting was measured as an interaction between the treatment (perturbed/unperturbed) and the year (Green, 1979). When this factor was significant, a posteriori comparisons were made using Tukey's test. A BACI design (Underwood, 1991, 1992) was not used in this study since we had a limited number of sampling dates before the perturbation occurred. However, we studied the temporal variation of the system using the time as factor (Archambault et al., 2001) and we did sample 1 year before the perturbation.

\section{Results}

Monthly, seasonal and annual climatic variables were similar throughout the 3 sampling years of this study (Table 2). TP concentrations ranged from 4.80 (perturbed, 2008) to $5.75 \mu \mathrm{g} \mathrm{L}^{-1}$ (perturbed, 2009) (Fig. 2). A statistically significant interaction between treatment and year was observed for TP concentrations (Table 3). A posteriori Tukey's test confirmed that unperturbed and perturbed lakes were not significantly different in 2008 (before forest harvesting) nor in 2010 but they were significantly different in 2009 (first year after forest harvesting). TP concentrations increased in the perturbed lakes in 2009 while it slightly decreased in unperturbed lakes. In $2010 \mathrm{TP}$ concentrations were practically the same in unperturbed and perturbed lakes, as a result of increased TP in reference lakes (Fig. 2). 

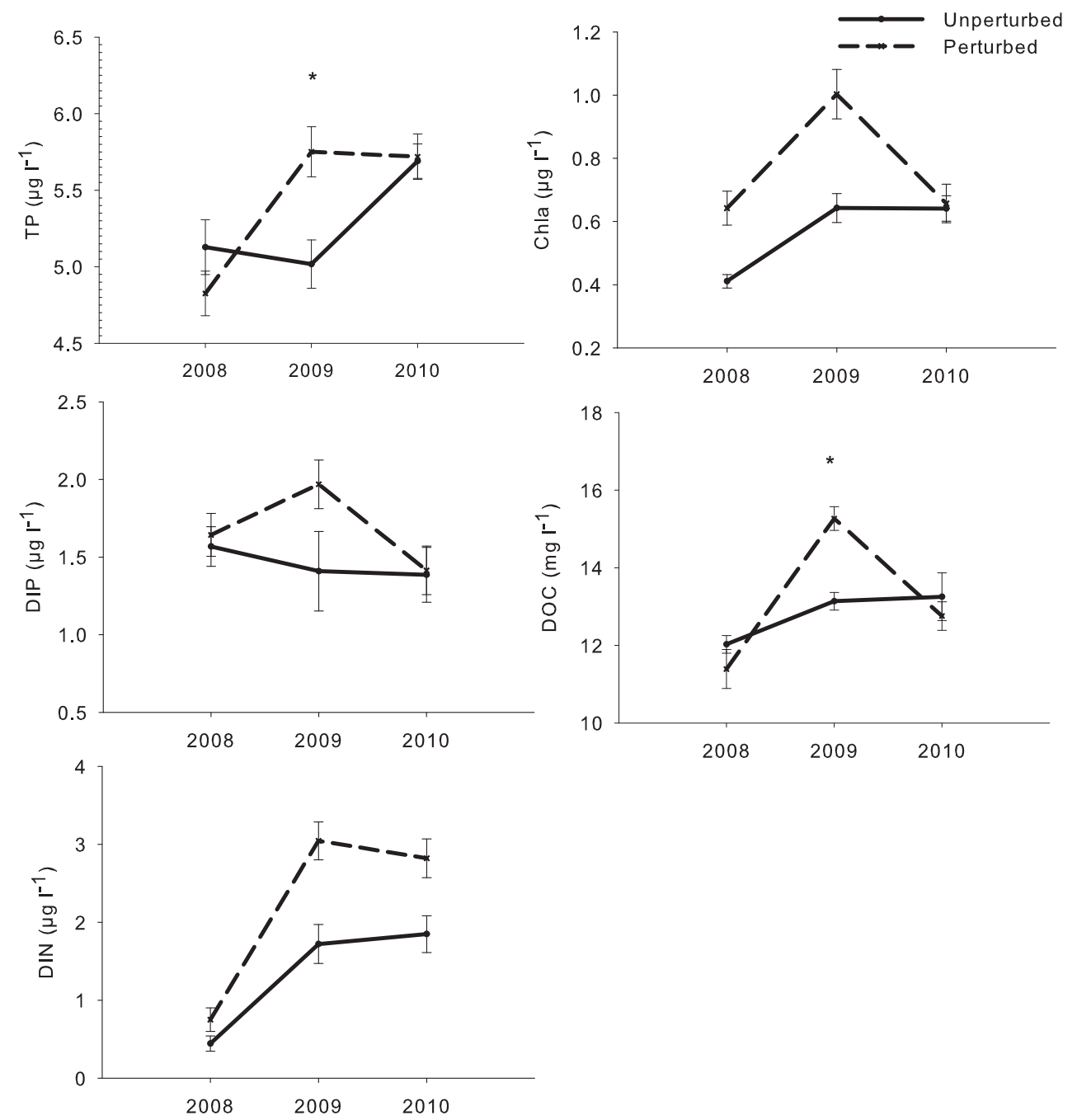

Figure 2. Comparison between treatments (unperturbed, perturbed) and years (2008, 2009, 2010) of TP, DIP, DIN, chl $a$ and DOC. Vertical bars represent standard errors. ${ }^{*} p<0.05$.

DIP values ranged from 1.39 (unperturbed, 2010) to $1.96 \mu \mathrm{g} \mathrm{L}^{-1}$ (perturbed, 2009) (Fig. 2) and DIN values ranged from 0.42 (unperturbed, 2008) to $3.02 \mu \mathrm{g} \mathrm{L}-1$ (perturbed, 2009) (Fig. 2). Neither DIP nor DIN values showed significant differences for the interaction between treatment and year (Table 3), although DIN values were higher in perturbed than unperturbed lakes in 2009 and 2010.

Chl $a$ values ranged from 0.41 (unperturbed, 2008) to $1.00 \mu \mathrm{g} \mathrm{L}^{-1}$ (perturbed, 2009) (Fig. 2). Chl $a$ values did not show significant differences between treatment and year (Table 3). Although there was an increase in chl $a$ concentration in 2009, this increase occurred for both unperturbed and perturbed lakes (Fig. 2).

DOC concentrations ranged from 11.34 (perturbed, 2008) to $15.27 \mathrm{mg} \mathrm{C} \mathrm{L}^{-1}$ (perturbed, 2009) (Fig. 2). No significant difference was detected between treatment and year for DOC values (Table 3). However, DOC was substantially higher in
2009 in perturbed lakes than in unperturbed lakes, then decreased in 2010 in perturbed lakes (Fig. 2). In 2009, DOC concentrations ranged from 9.57 to $14.96 \mathrm{mg} \mathrm{C} \mathrm{L}^{-1}$ in unperturbed lakes and from 13.60 to $17.48 \mathrm{mg} \mathrm{CL}^{-1}$ in perturbed lakes. Moreover, we performed a three-way ANOVA with the same factors as above but comparing only 2008 and 2009. In this case, the interactions between treatment and year for all the variables were significant for DOC concentrations $(\mathrm{d} f=2 / 12, \mathrm{MS}=32.3253, F=6.2160, p=0.0466)$ and $\mathrm{TP}(\mathrm{d} f=2 / 12, \mathrm{MS}=0.2561, F=20.9793, p=0.0036)$.

Two maxima humic-like peaks were observed in all EEM in all samples: peak A and peak C. These peaks are commonly reported in the literature (Coble, 1996; Parlanti et al., 2000) as indicators of the presence of humic substances. The spectroscopic metrics $a_{\mathrm{cDOM}}(355)$, fluorescence ratio A / C, FI, BIX, HIX, SUVA 254 and $S$ values showed similar patterns in unperturbed and perturbed lakes over time (Fig. 3). 
Table 3. Results of the three-way ANOVA testing the effect of treatment (tr : perturbed, unperturbed), lake, year and their interactions on TP, DIP, DIN, chl $a$ and DOC. Variables were transformed to achieve normality and homogeneity of variance. The principal source of variation of interest is the interaction between the treatment and the year of sampling. Significant $p$ values $(p<0.05)$ are in bold.

\begin{tabular}{llrrrrrr}
\hline Variable & & $\begin{array}{r}\text { Tr } \\
\end{array}$ & $\begin{array}{r}\text { Lake } \\
(\mathrm{tr})\end{array}$ & year & tr $\times$ year & $\begin{array}{r}\text { Lake } \\
(\mathrm{tr}) \times \text { year }\end{array}$ & Residual \\
\hline & $\mathrm{d} f$ & 1 & 6 & 2 & 2 & 12 & 96 \\
Log TP & SS & 0.07 & 0.01 & 0.18 & 0.15 & 0.02 & 0.02 \\
& $F$ & 5.30 & 0.63 & 8.46 & 6.75 & 1.07 & \\
& $p$ & 0.06 & 0.71 & $<\mathbf{0 . 0 5}$ & $<\mathbf{0 . 0 5}$ & 0.39 & \\
Log DIP & SS & 0.28 & 0.96 & 2.59 & 1.33 & 1.54 & 0.27 \\
& $F$ & 0.29 & 0.62 & 1.68 & 0.86 & 5.74 & \\
& $p$ & 0.61 & 0.71 & 0.23 & 0.44 & $<\mathbf{0 . 0 0 1}$ & \\
Log DIN & SS & 10.51 & 0.39 & 20.88 & 0.50 & 1.34 & 0.31 \\
& $F$ & 27.19 & 0.30 & 15.86 & 0.38 & 4.28 & \\
& $p$ & $<\mathbf{0 . 0 5}$ & 0.92 & $<\mathbf{0 . 0 0 1}$ & 0.69 & $<\mathbf{0 . 0 0 1}$ & \\
Log chl $a$ & SS & 3.07 & 0.69 & 3.29 & 0.29 & 0.23 & 0.13 \\
& $F$ & 4.41 & 2.30 & 14.18 & 1.25 & 1.25 & \\
& $p$ & 0.08 & 0.05 & $<\mathbf{0 . 0 0 1}$ & 0.32 & 0.07 & \\
Log DOC & SS & 0.01 & 0.13 & 0.38 & 0.13 & 0.07 & 0.01 \\
& $F$ & 0.06 & 1.92 & 5.34 & 1.79 & 14.01 & \\
& $p$ & 0.81 & 0.16 & $<\mathbf{0 . 0 5}$ & 0.21 & $<\mathbf{0 . 0 0 1}$ & \\
\hline
\end{tabular}

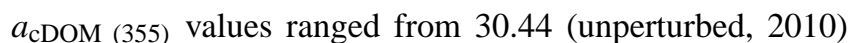
to $40.68 \mathrm{~m}^{-1}$ (perturbed, 2009) and showed the same pattern for unperturbed and perturbed lakes, increasing in 2009 and decreasing in 2010 (Fig. 3). Fluorescence ratio A / C values ranged from 1.46 (unperturbed, 2009) to 1.50 (perturbed, 2010) (Fig. 3) and FI values ranged from 1.64 (unperturbed, 2010) to 1.71 (unperturbed, 2009). FI values decreased in 2010 both for unperturbed and perturbed lakes (Fig. 3). BIX values ranged from 0.36 (unperturbed, 2009) to 0.40 (perturbed, 2010). HIX values ranged from 20.31 (perturbed, 2010 ) to 25.37 (unperturbed, 2009). SUVA 254 values ranged from 1.91 (perturbed, 2009) to $2.09 \mathrm{~L} \mathrm{mg} \mathrm{m}^{-1}$ (unperturbed, 2009) and $S$ values ranged from 0.010 (unperturbed, 2008) to $0.012 \mathrm{~nm}^{-1}$ (perturbed, 2010) (Fig. 3). No significant differences for the interaction between treatment and year were found for any of these variables (Table 4). Chl $a$ significantly correlated with DOC $\left(r^{2}=0.1202, F=14.0689\right.$, $p=0.001)$ and TP $\left(r^{2}=0.0693, F=7.5166, p=0.007\right)$ and DOC significantly correlated with TP $\left(r^{2}=0.2780\right.$, $F=8.2109, p=0.005)$. The absorption coefficient $\left(a_{(355)}\right)$ significantly correlated with DOC concentration in unperturbed and perturbed lakes $\left(r^{2}=0.7674, F=428.8325, p<\right.$ 0.001 ).

\section{Discussion}

Concentrations of TP measured in unperturbed and perturbed lakes were typical values reported for Boreal Shield lakes (Carignan et al., 2000; Winkler et al., 2009). However, logging disturbance increased the TP content of lakes 1 year after harvesting as also reported by other authors (Lamon- tagne et al., 2000; Winkler et al., 2009). Ground disturbance may increase weathering and leaching of phosphorus from exposed mineral soils (Evans et al., 2000). Adsorption of phosphorus to particles and their subsequent transportation by hydrological events can increase the loading of rivers and lakes (Whitson et al., 2005). Phosphorus losses from soils can be promoted by co-leaching with organic solutes such as DOC (Qualls et al., 1991). The presence of DOC can enhance the solubility, mobility and export of phosphorus by limiting the complexation of its dissolved form with cations that would otherwise react to precipitate phosphorus and retain it in soils. This would explain the significant correlation between DOC and TP found in this study. The parallel increase in TP and DOC in lakes, 1 year after harvesting, can suggest a rise in allochthonous import of DOC from watershed to lakes. DOC concentrations measured were typical of conifer boreal forest systems with a mean annual temperature of $2.5^{\circ} \mathrm{C}$ (Sobek et al., 2007). DOC concentrations significantly increased after harvesting in perturbed lakes, similar to Winkler et al. (2009), suggesting that the system responded immediately after the perturbation.

In lentic systems, DOC concentrations in surface waters are regulated by processes internal to lakes and external processes occurring in the watersheds where DOC are exported to lakes. In lakes, metabolic compounds released by healthy autotroph and heterotroph organisms, exudation from altered cells resulting from zooplankton grazing and microbial decay of soft tissues of dead organisms may produce or deliver DOC in lakes. DOC can also be removed from water by bacterial degradation, photolytic alteration, heterotrophic respiration (i.e., $\mathrm{CO}_{2}$ evasion) and sorption or aggregation 

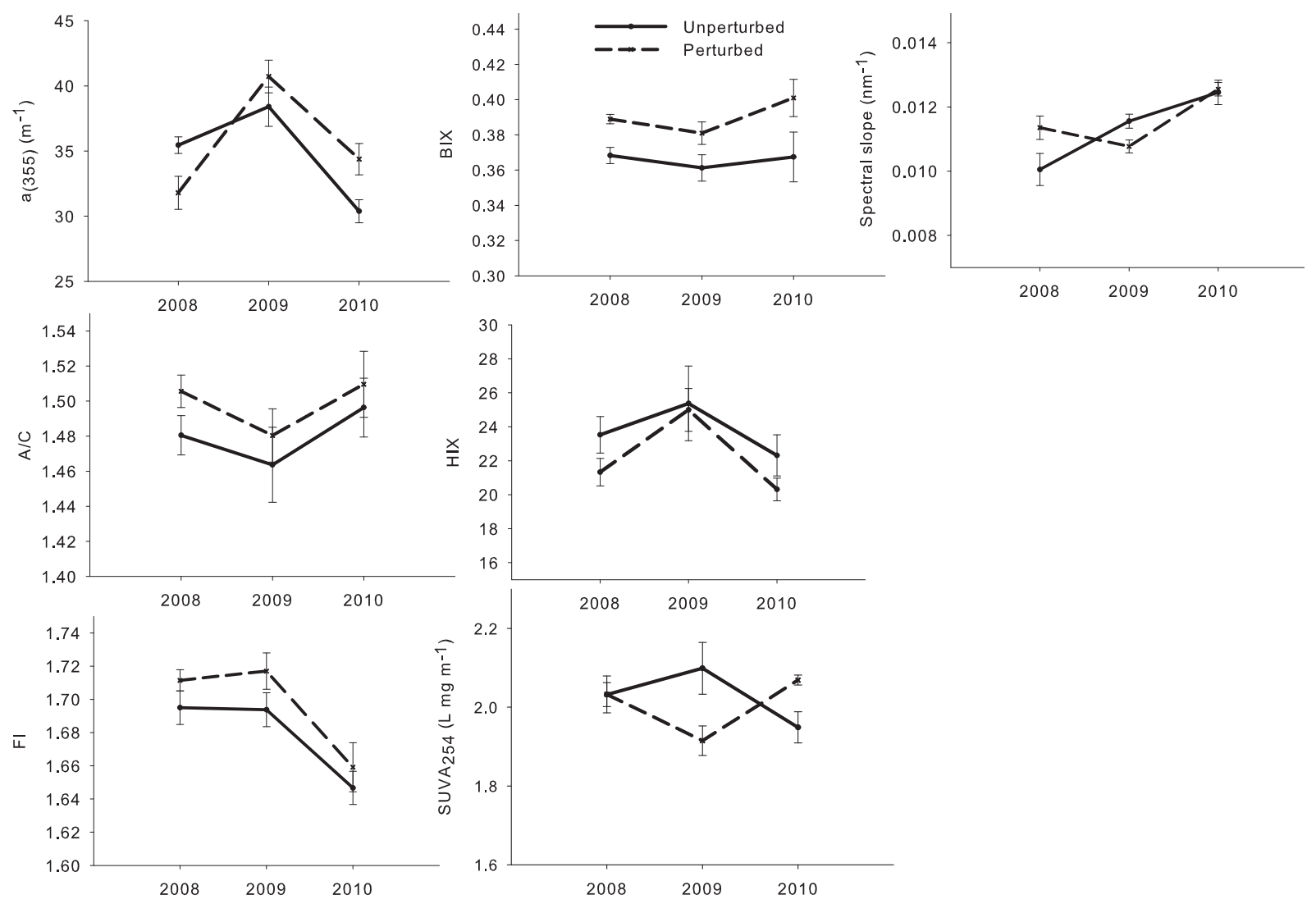

Figure 3. Comparison between treatments (unperturbed, perturbed) and years $(2008,2009,2010)$ of $a_{\mathrm{cDOM}}(\lambda=355)$, A / C, FI, BIX, HIX, $\mathrm{SUVA}_{254}$ and spectral slope. Vertical bars represent standard errors.

between organic matter and clays that cause sedimentation of particles. As mentioned earlier, the increase in DOC could result from the extracellular release of DOC from phytoplankton (Baines and Pace, 1991). However, the increase observed in DOC 1 year after harvesting is not parallel with a rise in chl $a$ content, suggesting a minor role of phytoplankton exudates on the regulation of DOC level. This is also supported by the absence of characteristic protein-like peaks associated to planktonic production (excitation maxima at 275 and 305-340 nm (Coble, 2007) in our EEM fluorescence spectra (data not shown). Furthermore, the lakes are shallow and hot in summer $\left(15-18^{\circ} \mathrm{C}\right.$ in July). Under these conditions, bacterial mineralization of labile organic matter can be efficient and net production of DOC in lakes should be low. If processes occurring in lakes act as an important sink (destruction or sedimentation) for organic matter, it is the production and transport of DOC from the catchment areas to lakes that control the quantity and quality of organic matter in lakes. The mean annual lake residence times of water in the lakes studied are short, less than 0.16 years (Table 1 ). Then, a rapid turnover of water and a quick replacement of DOC occur in these lakes. Under these conditions, variations in quantity and quality of DOC suggest that processes occurring in the drainage basins are of paramount importance to explain changes in the amounts and the chemical composition of DOC in lakes.

The transport of DOM from terrestrial ecosystems to lakes is complex. Thus, several potential processes could give rise to an increase in DOC content in lakes. Many studies suggested that the most important processes to explain increases in DOC after forest harvesting was the rise in organic matter leaching from logging slash; the increase decomposition of organic logging residues and organic matter in the surface soils due to increased forest floor temperature and moisture; and a reduction in evapotranspiration causing an increase in runoff quantity leading to a higher water table favorable to the exportation of DOM from the surface and riparian soils (Qualls et al., 2000; Bishop et al., 2004; Kreutzweiser et al., 2008; Schelker et al., 2013b). However, the largest Cefflux from a forest floor is soil respiration, which has been shown to change as a result of forest disturbance (Grant et al., 2007). Leaching from logging slash or foliage and woody debris mixed to surface soils after forest harvesting could enrich water soil surface in organic components (Qualls et al., 2000). However, studies show that amounts of DOC leached vary with temperature, the nature of woody debris and the lability of organic matter. Coarse residues (stumps, coarse roots, branches) decompose slowly while fine residues 
Table 4. Results of the three-way ANOVA testing the effect of treatment (tr: perturbed, unperturbed), lake, year and their interactions on absorbance coefficients of CDOM $\left(a_{\mathrm{cDOM}}\right)$ at $355 \mathrm{~nm}, \mathrm{~A} / \mathrm{C}$ peak ratios, fluorescence index (FI), biological/autochthonous index (BIX), humification index (HIX), specific UV absorbance at $254 \mathrm{~nm}\left(\mathrm{SUVA}_{254}\right)$ and spectral slope $(S)$. The principal source of variation of interest is the interaction between the treatment and the year of sampling. Significant $p$ values $(p<0.05)$ are in bold.

\begin{tabular}{|c|c|c|c|c|c|c|c|}
\hline Variable & & $\operatorname{tr}$ & lake (tr) & year & $\operatorname{tr} \times$ year & lake $(\operatorname{tr}) \times$ year & Residual \\
\hline & $\mathrm{d} f$ & 1 & 6 & 2 & 2 & 12 & 48 \\
\hline \multirow{3}{*}{$a_{\mathrm{cDOM}}(\lambda=355)$} & SS & 6.81 & 316.26 & 137.19 & 133.38 & 110.28 & 14.95 \\
\hline & $F$ & 0.02 & 3.22 & 1.35 & 1.31 & 7.37 & \\
\hline & $p$ & 0.88 & $<0.05$ & 0.29 & 0.30 & $<0.001$ & \\
\hline \multirow[t]{3}{*}{$\mathrm{A} / \mathrm{C}$} & SS & 0.02 & 0.01 & 0.01 & 0.01 & 0.01 & 0.01 \\
\hline & $F$ & 0.85 & 4.51 & 1.13 & 0.83 & 2.16 & \\
\hline & $p$ & 0.39 & $<0.05$ & 0.29 & 0.39 & $<0.05$ & \\
\hline \multirow[t]{3}{*}{ FI } & SS & 0.01 & 0.01 & 0.02 & 0.01 & 0.01 & $<0.001$ \\
\hline & $F$ & 1.02 & 1.89 & 21.92 & 0.88 & 2.62 & \\
\hline & $p$ & 0.35 & 0.16 & $<0.001$ & 0.35 & $<0.05$ & \\
\hline \multirow[t]{3}{*}{ BIX } & SS & 0.01 & 0.01 & 0.01 & 0.01 & 0.01 & $<0.001$ \\
\hline & $F$ & 4.65 & 1.42 & 3.98 & 0.24 & 4.12 & \\
\hline & $p$ & 0.08 & 0.28 & 0.05 & 0.62 & $<0.001$ & \\
\hline \multirow[t]{3}{*}{ HIX } & SS & 35.97 & 287.71 & 140.16 & 9.47 & 222.06 & $<0.001$ \\
\hline & $F$ & 2.55 & 9.56 & 4.97 & 0.33 & 3.69 & \\
\hline & $p$ & 0.11 & $<0.05$ & $<0.05$ & 0.71 & $<0.001$ & \\
\hline \multirow[t]{2}{*}{ SUVA $_{254}$} & SS & 0.09 & 0.22 & 0.72 & 0.35 & 0.36 & $<0.001$ \\
\hline & $F$ & 4.14 & 0.63 & 2.07 & 1.01 & 5.56 & \\
\hline \multirow[t]{3}{*}{$S$} & SS & $1.6510^{-6}$ & $8.610^{-6}$ & $3.3210^{-5}$ & $7.4310^{-6}$ & $5.5910^{-6}$ & $1.3910^{-6}$ \\
\hline & $F$ & 0.20 & 1.59 & 6.25 & 1.40 & 4.24 & \\
\hline & $p$ & 0.67 & 0.23 & $<0.05$ & 0.28 & $<0.001$ & \\
\hline
\end{tabular}

(leaves, needles, fine roots, twigs) as well as boreal forest moss and feather mosses can be very quickly metabolized to $\mathrm{CO}_{2}$ (Wickland et al., 2007; Hanson et al., 2010). During the degradation processes, nitrogen, and low molecular weight organic acids are first removed while lignin and humic substances could persist. Qualls et al. (2000) suggested that higher concentrations of dissolved organic nutrients in solution draining from the forest floor of the cut plots can largely be accounted for by the slash above the leaf litter of the forest floor.

The input of DOM to lakes from surrounding landscape could produce changes in the amount and the chemical composition or quality of organic matter. However, although total DOC concentrations increased 1 year after logging, the composition of DOC did not measurably change. This result has also been reported in streams (Burrows et al., 2014). Three-dimensional excitation-emission fluorescence spectra of lake samples studied over 3 years shown only two major fluorophores associated with allochthonous humic-like components. This constancy in composition suggests that DOC composition was similar for the 3 years in unperturbed and perturbed lakes, since there was no significant difference between year and treatment for the ratio of fluorescence intensity of the two humic-like peaks (A/C) and since no differences were observed on the UV-VIS spectra between the 3 years (data not shown). Moreover, FI, BIX and HIX indices showed no significant differences either, indicating there was no change in fluorescence spectra due to logging. FI is an index of the origin of fulvic acids. In this study, FI values were around 1.65 in all lakes and years. Cory et al. (2010) suggested values near 1.2 for DOM of terrestrial origin in a large river of USA and 1.55 for microbially derived DOM. However, Korak et al. (2014) have recently shown that FI values can vary by 0.2 units if concentration changes, the highest FI value measured at low DOC concentration. In this study, our measurements were obtained at natural $\mathrm{pH}$, about 5.5 in the lakes studied. Measurements of FI at samples pH other than 6-7.5 as suggested by McKnight et al. (2001) or Cory et al. (2010) could change the range of values used to distinguish sources of DOM because protonation, molecular conformation and fluorescence signal of DOM change with $\mathrm{pH}$. Thus, the relative contribution of autochthonous and allochthonous material cannot be discerned from FI values. BIX values were, however, between 0.35 and 0.42 . These results are below 0.7 , suggesting that DOM contains very little autochthonous organic matter, and it may be mainly composed of allochthonous matter (Vacher, 2004; Birdwell and Engel, 2010). Finally, HIX values were between 20.31 and 25.37 , in the range of values reported for soil-derived humics (Birdwell and Engel, 2010). This is in agreement with Vacher (2004), who suggested that HIX values larger than 16 indicate a strong humic character and an important terrigenous contribution. 
SUVA $_{254}$ values (1.91 to 2.09 ) were slightly lower than values reported in other studies in boreal forests (Wickland et al., 2007; Balcarczyk et al., 2009), indicating a relatively low aromaticity for DOC. Wickland et al. (2007) reported low SUVA values (between 1.9 and 2.3) for well- or moderately drained soils. They associate the low value of SUVA to the presence of hydrophilic organic matter (HPIOM). Guggenberger et al. (1994) found that HPIOM appeared to be partly microbially synthesized and partly plant-derived with a high degree of oxidative biodegradation suggesting that HPIOM are relatively small molecules with many oxidized side-chains. $S$ values were similar to values found in other studies in boreal forest systems (Galgani et al., 2011). Our results showed no significant difference of $\mathrm{SUVA}_{254}$ or $S$ values (taking into account the interaction between the treatment and the year of sampling). This suggests that forest harvesting resulted in an increase in the quantity of DOC available (as DOC concentrations were significantly higher in 2009) without changes in terms of quality. DOC quality varies to a large extent depending on its terrestrial origin in terms of bioavailability (Berggren et al., 2007; Ågren et al., 2008). As the fluorescence can help to differentiate between plant and microbially synthesized DOC (McKnight et al., 2001), increased runoff after harvesting would have resulted in DOC increases but DOC had a very close composition before and after harvesting. Similar findings were reported in 23 forested lakes in central Quebec, where DOC concentrations increased in logged lakes, but no changes in aromaticity of DOC were observed (O'Driscoll et al., 2006).

In this study, we measured DOC and optical properties of organic matter to provide information on the amount, quality, and origin of organic matter. DOC increases 1 year after harvesting, but this rise is not accompanied by variations in spectroscopic parameters $a_{\mathrm{CDOM}}$ (355), fluorescence ratio A / C, FI, BIX, HIX, SUVA 254 and $S$. What concludes from these results? At least two points can contribute to our observations. An increase in DOC without change in spectroscopic metrics means that the DOC introduced in the system does not absorb or fluoresce following UV-VIS irradiation. If compounds have double bonds or aromatic moieties, these compounds will absorb light and give alteration in spectroscopic metrics, not observed in this study. However, if dissolved organic matter contains mostly sigma chemical bonds, these bonds could be hidden to the metrics used because sigma bonds absorb near $200 \mathrm{~nm}$ far from the wavelengths $(>254 \mathrm{~nm}$ ) used in the proxies measured. This suggests that low molecular weight organic acids, hydrocarbons, lipids, or carbohydrates can contribute to the rise in DOC without change in spectroscopic properties in the UV-VIS wavelength. Low molecular weight organic acids are used rapidly by bacteria (Romero-Kutzner et al., 2015). Their occurrence in DOC is unlikely. However, hydrocarbons, lipids and carbohydrates exist in plants (Kögel-Knabner, 2002) and simple sugars and nonhumic-bound polysaccharides could contribute to the increment in DOC at least for deciduous forest ecosystem (Qualls and Haines, 1991). In a study on the release of DOC from plant tissues, Moore and Dalva (2001) observed that DOC leaching is more efficient from fresh material than from old material. This could contribute to the higher level of DOC 1 year after logging. The composition of the new DOC could be lipid-like or carbohydrate-like compounds.

Our fluorescence results suggest that humic substances are the ubiquitous compounds exported to lakes. The decrease in evapotranspiration following the clearing forest vegetation (causing a change in the hydrologic regime) and the leaching of logging slash could contribute to a selective washing of humic substances. Boyer et al. (1996) suggested that DOC in upper soil might accumulate during periods of low flow and be exported during periods of high flows. However, DOC in deep soils horizons could be immobilized through sorption onto mineral phases or by precipitation with polyvalent cations (Qualls et al., 2000; Hansson et al., 2010; Kaiser and Kalbitz, 2012). The sorption could be more effective to retain humic than fulvic acids (Weng et al., 2006). Moreover, washing of logging slash can decrease the $\mathrm{pH}$ by 0.9 units for leachate of fresh needle litter (Hansson et al., 2010). Such reduction in $\mathrm{pH}$ could decrease the solubility of humic substances by more than $50 \%$ (Tipping and Woof, 1990) and cause a stronger sorption of humic acids compared to fulvic acids (Weng et al., 2006). However, because fulvic acids are soluble at any $\mathrm{pH}$, by definition, it is the apparent solubility of humic acids that decrease during leaching of logging slash and through transport of DOC from watershed to lakes. The resulting effect will be a possible enrichment of water soil surface in fulvic acids exported to lakes. The spectroscopic parameters measured are in agreement with our hypothesis that DOC is mainly composed of fulvic acids.

Although there appears to be a recovery of water chemistry (TP and DOC) by year 2, there are confounding factors that can obscure real recovery or delayed effects. For example, Schelker et al. (2012) have seen a long lasting forestry effect on both hydrology and DOC on aquatic systems in the boreal region. Biogeochemical processes in watersheds do not all respond immediately to logging effects, i.e., tree removal and ground disturbance. Some processes may take a few years, such as changes in organic matter composition and processing on the forest floor, changes in vegetation composition from which the DOC is derived, before those changes affect export of nutrients and subsequent changes to lake water chemistry. Also, hydrological conditions (especially runoff) greatly affect solute movement to surface waters (Fawcett et al., 1994), and it is possible that year 2 was different hydrologically than the preceding and may have masked delayed effects. Inter-annual variability could also have affected the export of nutrients and DOC to the lakes. However, since monthly, seasonal and annual climatic variables were similar throughout the 3 years of sampling (Table 2), we can then assume that in this study, forest harvesting is a major factor influencing the system comparing to a natural factor such 
as annual precipitation. Lastly, carbon and nutrients can be transformed (i.e., immobilized, mineralized, evaded as $\mathrm{CO}_{2}$ ) before being input into lakes (Ledesma et al., 2015). There is thus the potential for substantial changes in many of the lake water parameters measured before they enter each lake.

In conclusion, this study indicated that logging activities appeared to increase significantly TP and DOC export to oligotrophic lakes of the eastern Canadian Boreal Shield 1 year after the perturbation. This impact on water chemistry due to logging activity appeared to have been short-term with recovery to pre-logging conditions 2 years after harvest. Nevertheless, it has to be kept in mind that the number of perturbed and unperturbed lakes in this study was only four, and that they were sampled 1 month each year due to logistic constraints. Sampling multiple times per year at each lake would have permitted to estimate the influence that seasonal and natural events (i.e., snow melt and storms) have upon the response parameters. Furthermore, the study did not address the potential for delayed or longer-term changes in water chemistry that could result from biogeochemical processes in the lake catchments adjusting to forest recovery after harvest. However, this 3-year period study shows interesting results. It suggests changes in DOC and TP keeping the quality of the CDOM almost unaffected. Moreover, the spectroscopic data converge to suggest that fulvic acids are the mobile form of CDOM carried to lakes and that fulvic acids respond rapidly to forest harvesting contrary to humic acids. Fulvic and humic acids are the most important components of DOC and CDOM.

Acknowledgements. This research project was supported by a public grant from the Fonds Québécois de la Recherche sur la Nature et les Technologies (FQRNT) to C. Nozais and P. Sirois and by grants from the Natural Sciences and Engineering Research Council of Canada to C. Nozais and J.-P. Gagné. P. Glaz was supported by a $\mathrm{PhD}$ fellowship from FQRNT. We are grateful to people who contributed to the sampling in the field: Myriam Bergeron, Yan Bhérer, Gabriel Diab, Dominic Gauthier, Philippe Beaulieu, Vanessa Paradis, Tommy Larouche, Hubert Philippon, Katrine Chalut and Geneviève Brouillet-Gauthier. We also thank AbitibiBowater Inc. for providing land use information and field facilities, R. Carignan for his contribution on determination of TP and T. Buffin-Bélanger for providing help with hydrological analysis. This manuscript was improved by M. González, M. Vanni and their laboratories affiliates. Three anonymous reviewers provided pertinent and helpful comments on the manuscript. This is a contribution to the research programs of Centre d'études nordiques (CEN), Centre de la science de la biodiversité du Québec (CSBQ), Centre de recherche sur la Boréalie and to the Chaire de recherche sur les espèces aquatiques exploitées.

Edited by: B. A. Pellerin

\section{References}

Ågren, A., Berggren, M., Laudon, H., and Jansson, M.: Terrestrial export of highly bioavailable carbon from small boreal catchments in spring floods, Freshwater Biol., 53, 964-972, 2008.

Archambault, P., Banwell, K., and Underwood, A. J.: Temporal variation in the structure of intertidal assemblages following the removal of sewage, Mar. Ecol. Prog. Ser., 222, 51-62, 2001.

Baines, S. B, and Pace, M. L.: The production of dissolved organic matter by phytoplankton and its importance to bacteria: Patters across marine and freshwater systems, Limnol. Oceanogr., 36, 1078-1090, 1991.

Balcarczyk, K. L., Jones, J. B., Jaffe, R., and Maie, N.: Stream dissolved organic matter bioavailability and composition in watersheds underlain with discontinuous permafrost, Biogeochemistry, 94, 255-270, 2009.

Berggren, M., Laudon, H., and Jansson, M.: Landscape regulation of bacterial growth efficiency in boreal freshwaters, Global Biogeochem. Cy., 21, GB4002, doi:10.1029/2006GB002844 2007.

Birdwell, J. E., and Engel, A. S.: Characterization of dissolved organic matter in cave and spring waters using UV-Vis absorbance and fluorescence spectroscopy, Org. Geochem., 41, 270-280, 2010.

Bishop, K., Seibert, J., Köhler, S., and Laudon, J.: Resolving the double paradox of rapidly mobilized old water with highly variable responses on runoff chemistry, Hydrol. Proc., 18, 185-189, 2004.

Bormann, F. H. and Likens, G.: Pattern and process in a forested ecosystem: disturbance, development and the steady state based on the Hubbard Brook ecosystem study, Springer-Verlag, New York, 1994.

Bosch, J. M. and Hewlett, J. D.: A review of catchment experiments to determine the effect of vegetation changes on water yield and evaporation, J. Hydrol., 55, 3-23, 1982.

Boyer, E. W., Hornberger, G. M., Bencala, K. E., and McKnight, D.: Overview of a simple model describing variation of dissolved organic carbon in an upland catchment, Environ. Ecol. Mod. Simul. Manage., 86, 183-188, 1996.

Burrows, R. M., Magierowski, R. H., Fellman, J. B., Clapcott, J. E., Munks, S. A, Roberts, S., Davies, P. E., and Barmuta, L. A: Variation in stream organic matter processing among years and benthic habitats in response to forest clearfelling, For. Ecol. Manage., 327, 136-147, 2014.

Buttle, J. M., Creed, I. F., and Moore, R. D.: Advances in Canadian forest hydrology, 1999-2003, Hydrol. Proc., 19, 169-200, 2005.

Carignan, R., D'Arcy, P., and Lamontagne, S.: Comparative impacts of fire and forest harvesting on water quality in Boreal Shield lakes, Can. J. Fish. Aq. Sci., 57, 105-117, 2000.

Coble, P. G.: Characterization of marine and terrestrial DOM in seawater using excitation-emission matrix spectroscopy, Mar. Chem., 51, 325-346, 1996.

Coble, P. G.: Marine optical biogeochemistry: The chemistry of ocean color. Chem. Rev., 107, 402-418, 2007.

Cory, R. M. and McKnight, D. M.: Fluorescence spectroscopy reveals ubiquitous presence of oxidized and reduced quinones in dissolved organic matter, Environ. Sci. Technol., 39, 8142-8149, 2005.

Cory, R. M., McNeill, K., Cotner, J. P., Amado, A., Purcell, J. M., and Marshall A. G.: Singlet oxygen in the coupled photochemi- 
cal and biochemical oxidation of dissolved organic matter, Environ. Sci. Technol. 44, 3683-3689, 2010.

Deflandre, B. and Gagné, J.-P.: Estimation of dissolved organic carbon (DOC) concentrations in nanoliter samples using UV spectroscopy, Water Res., 35, 3057-3062, 2001.

Evans, J. E., Prepas, E. E., Devito, K. J., and Kotak, B.G.: Phosphorus dynamics in shallow subsurface waters in an uncut and cut subcatchment of a lake on the Boreal Plain, Can. J. Fish. Aq. Sci., 57, 60-72, 2000.

Fawcett, R. S., Christensen, R. B., and Tierney, D. P.: The impact of conservation tillage on pesticide runoff into surface water: A review and analysis, J. Soil Water Conserv., 49, 126-135, 1994.

Fellman, J. B., D'Amore, D. V., and Hood, E.: An evaluation of freezing as a preservation technique for analyzing dissolved organic $\mathrm{C}, \mathrm{N}$ and $\mathrm{P}$ in surface water samples, Sci. Total Environ., 392, 305-312, 2008.

Fellman, J. B., Hood, E., and Spencer, R. G. M.: Fluorescence spectroscopy opens new windows into dissolved organic matter dynamics in freshwater ecosystems: A review, Limnol. Oceanogr., 55, 2452-2462, 2010.

Fichot, C. and Benner, R.: The spectral slope coefficient of chromophoric dissolved organic matter $\left(S_{275-295}\right)$ as a tracer of terrigenous dissolved organic carbon in river-influenced ocean margins, Limnol. Oceanogr., 57, 1453-1466, 2012.

Findlay, S. E. G. and Sinsabaugh, R. L.: Aquatic Ecosystems: Interactivity of dissolved organic matter, Academic Press, California, 2003

Galgani, L., Tognazzi, A., Rossi, C., Ricci, M., Galvez, J. A., Dattilo, A. M., Cozar, A., Bracchini, L., and Loiselle, S. A.: Assessing the optical changes in dissolved organic matter in humic lakes by spectral slope distributions, J. Photochem. Photobiol., 102, 132-139, 2011.

Grant, R. F., Barr, A. G., Black, T. A., Gaumont-Guay, D., Iwashita, H., Kidson, J., McCaughey, H., Morgenstern, K., Murayama, S., Nesic, Z., Saigusa, N., Shashkov, A., and Zha, T.: Net ecosystem productivity of boreal jack pine stands regenerating from clearcutting under current and future climates, Glob. Change Biol., 13, 1423-1440, 2007.

Green, R. H.: Sampling design and statistical methods for environmental biologists, Wiley, Chichester, 1979.

Groot, A., Lussier, J.-M., Mitchell, A. K., and MacIsaac, D. A.:A silvicultural systems perspective on changing forestry practices, Forest Chronol., 81, 50-55, 2005.

Guggenberger, G., Zech, W., and Schulten, H. R.: Formation and mobilization pathways of dissolved organic matter: evidence from chemical structural studies of organic matter fractions in acid forest floor solutions, Org. Geochem., 21, 51-66, 1994.

Hansson, K., Kleja, D. B., Kalbitz, K., and Larsson, H.: Amounts of carbon mineralised and leached as DOC during decomposition of Norway spruce and roots, Soil Biol. Biochem., 42, 178-185, 2010.

Hudson, N., Baker, A., and Reynolds, D.: Fluorescence analysis of dissolved organic matter in natural, waste and polluted waters a review, River Res. Appl., 23, 631-649, 2007.

Huguet, A., Vacher, L., Relexans, S., Saubusse, S., Froidefond, J. M., and Parlanti, E.: Properties of fluorescent dissolved organic matter in the Gironde Estuary, Org. Geochem., 40, 706-719, 2009.
Jaffé, R., McNight, D., Maie, N., Cory, R., McDowell, W. H., and Campbell, J. L.: Spatial and temporal variations in DOM composition in ecosystems: The importance of long-term monitoring of optical properties, J. Geophys. Res., 113, G04032, doi:10.1029/2008JG0006832008.

Kaiser, K. and Kalbitz, K.: Cycling downard-dissolved organic matter in soils, Soil Biol. Biochem., 52, 29-32, 2012.

Kelton, N., Molot, L. A., and Dillon, P. J.: Spectrofluorometric properties of dissolved organic matter from Central and Southern Ontario streams and the influence of iron and irradiation, Water Res., 41, 638-646, 2007.

Kirk, J. T. O.: Light and Photosynthesis in Aquatic Ecosystems, Second Edition, Cambridge Univerity Press, 1994.

Korak, J. A., Dotson, A. D., Summers, R. S., and Rosario-Ortiz, F. L.: Critical analysis of commonly used fluorescence metrics to characterize dissolved organic matter, Water Res., 49, 327-338, 2014.

Kreutzweiser, D. P., Hazlett, P. W., and Gunn, J. M.: Logging impacts on the biogeochemistry of boreal forest soils and nutrient export to aquatic systems: A review, Environ. Rev., 16, 157-159, 2008.

Kögel-Knabner, I.: The macromolecular organic composition of plant and microbial residues as inputs to soil organic matter, Soil Biol. Biochem., 34, 139-162, 2002.

Lakowicz, J. R.: Principles of fluorescence spectroscopy, 3rd Edn., Springer, 2006.

Lamontagne, S., Carignan, R., D’Arcy, P., Prairie, Y. T., and Paré, D.: Element export in runoff from eastern Canadian Boreal Shield drainage basins following forest harvesting and wildfires, Can. J. Fish. Aq. Sci., 57, 118-128, 2000.

Laudon, H., Hedtjärn, J., Schelker, J., Bishop, K., Sørensen, R., and Ågren, A.: Response of dissolved organic carbon following forest harvesting in a boreal forest, Ambio, 38, 381-386, 2009.

Ledesma, J. L. J., Grabs, T., Bishop, K. H., Schiff, S. L., and Köhler, S. J.: Potential for long-term transfer of dissolved organic carbon from riparian zones to streams in boreal catchments, Glob. Change Biol., 21, 2963-2979, 2015.

Löfgren, S., Ring, E., von Brömsen, C., Sørensen, R., and Högbom, L.: Short-term effects of forest harvesting on the water chemistry in two boreal streams in northern Sweden: a paired catchment study, Ambio, 38, 347-356, 2009.

McKnight, D. M., Boyer, E. W., Westerhof, P. K., Doran, P. T., Kulbe, T., and Anderson, D. T.: Spectrofluorometric characterization of dissolved organic matter for indication of precursor organic material and aromaticity, Limnol. Oceanogr., 46, 38-48, 2011.

Mobed, J. J., Hemmingsen, S. L., Autry, J. L., and McGown, L. B. Fluorescence characterization of IHSS humic substances: total luminescence spectra with absorbance correction, Environ. Sci. Technol., 30, 3061-3065, 1996.

Moore, T. R. and Dalva, M. Soem control on the release of dissolved organic carbon by plant tissues and soils, Soil Sci., 166, 38-47, 2001.

NRCan: The state of Canada's forests 2004-2005, the boreal forest. Natural Resources Canada, Canadian Forest Service, Ottawa, Ontario, 2005.

O’Driscoll, N. J., Siciliano, S. D., Peak, D., Carignan, R., and Lean, D. R. S.: The influence of forestry activity on the structure of 
dissolved organic matter in lakes: Implications for mercury photoreactions, Sci. Total Environ., 366, 880-893, 2006.

Parlanti, E., Wörz, K., Geoffroy, L., and Lamotte, M.: Dissolved organic matter fluorescence spectroscopy as a tool to estimate biological activity in a coastal zone submitted to anthropogenic inputs, Org. Geochem., 31, 1765-1781, 2000.

Qualls, R. G. and Haines, B. L.: Geochemistry of dissolved organic nutrient in water percolating through a forest ecosystem, Soil Sci. Soc. Am. J., 55, 1112-1123, 1991.

Qualls, R. G., Haines, B. L., and Swank, W. T.: Fluxes of dissolved organic carbon and humic substances in a deciduous forest, Ecology, 72, 254-266, 1991.

Qualls, R. G., Haines, B. L., Swank, W. T., and Tyler, S. W.: Soluble organic and inorganic nutrient fluxes in clearcut and mature deciduous forests, Soil Sci. Soc. Am. J., 64, 1068-1077, 2000.

Rask, M., Nyberg, K., Markkanen, S. L., and Ojala, A.: Forestry in catchments: Effects on water quality, plankton, zoobenthos and fish in small lakes, Boreal Environ. Res., 3, 75-86, 1998.

Romero-Kutzner, V., Packard, T. T., Berdalet, E., Roy, S. O., Gagné, J.-P., and Gomez, G.: Respiration quotientvariability: bacterial evidence, Mar. Ecol. Prog. Ser., 519, 47-59, 2015.

Schelker, J., Eklöf, K., Bishop, K., and Laudon, H.: Effects of forestry operations on dissolved organic carbon (DOC) concentrations and export in boreal first-order streams, J. Geophys. Res.-Biogeosci., 117, G01011, doi:10.1029/2011JG001827, 2012.

Schelker, J., Kuglerová, L., Eklöf, K., Bishop, K., and Laudon, H. Hydrological effects of clear-cutting in a boreal forest - Snowpack dynamics, snowmelt and streamflow responses, J. Hydrol., 484, 105-114, 2013a.

Schelker, J., Grabs, T., Bishop, K., and Laudon, H.: Drivers of increased organic carbon concentrations in stream water following forest disturbance: Separating effects of changes in flow pathways and soil warming, J. Geophys. Res.-Biogeosci., 118, 18141827, doi:10.1002/2013JG002309, 2013b.

Schindler, D. W., Bayley, S.E., Curtis, P. J., Parker, B. R., Stainton, M. P., and Kelly, C. A.: Natural and man-caused factors affecting the abundance and cycling of dissolved organic substances in precambrian shield lakes, Hydrobiologia, 229, 1-21, 1992.

Smith, D. W., Prepas, E. E., Putz, G., Burke, J. M., Meyer, W. L., and Whitson, I.: The forest watershed and riparian disturbance study: a multi-discipline initiative to evaluate and manage watershed disturbance on the Boreal Plain of Canada, J. Environ. Eng. Sci., 2, S1-S13, 2003.

Sobek, S., Tranvik, L. J., Prairie, Y. T., Kortelainen, P., and Cole, J. J.: Patterns and regulation of dissolved organic carbon: An analysis of 7,500 widely distributed lakes, Limnol. Oceanogr., 52, 1208-1219, 2007.

Stainton, M. P., Capel, M. J., and Armstrong, F. A. J.: The chemical analysis of fresh water, 2nd Edn., Can. Fish. Mar. Serv. Misc. Spec. Publ. No., 25, 109-110, 1977.

Stedmon, C. A., Markager, S., and Bro, R.: Tracing dissolved organic matter in aquatic environments using a new approach to fluorescence spectroscopy, Mar. Chem., 82, 239-254, 2003.
Tipping, E. and Woof, C.: Humic substances in acid organic soils: modelling their release to the soil solution in terms of humic charge, J. Soil Sci., 41, 573-586, 1990.

Tremblay, L. and Gagné, J.-P.: Organic matter distribution and reactivity in the waters of a large estuarine system, Mar. Chem., 116, 1-12, 2009.

Underwood, A. J.: Beyond BACI: Experimental designs for detecting human environmental impacts on temporal variations in natural populations, Aust. J. Mar. Freshwater Res., 42, 569-587, 1991.

Underwood, A. J.: Beyond BACI - the detection of environmental impacts on populations in the real, but variable, world, J. Exp. Mar. Biol. Ecol., 161, 145-178, 1992.

Vacher, L.: Étude par fluorescence des propriétés de la matière organique dissoute dans les systèmes estuariens. Cas des estuaires de la Gironde et de la Seine, Ph.D. Thesis, Université Bordeaux I, Bordeaux, France, 2004.

Weishaar, J. L., Aiken, G. R., Bergamaschi, B. A., Fram, M. S., Fujii, R., and Mopper, K.: Evaluation of specific ultraviolet absorbance as an indicator of the chemical composition and reactivity of dissolved organic carbon, Environ. Sci. Technol., 37, 47024708, 2003.

Welschmeyer, N. A.., Strom, S., Goericke, R., Ditullio, G., Belvin, M., and Petersen, W.: Primary production in the sub-arctic pacific-ocean - project super, Prog. Oceanogr., 32, 101-135, 1994.

Weng, L., van Riemsdijk, W. H., Koopal, L. K., and Hiemstra, T.: Adsorption of humic substances on goethite: comparison between humic acids and fulvic acids, Environ. Sci. Technol., 15, 7494-7500, 2006.

Whitehead, R. F., De Mora, S., Demers, S., Gosselin, M., Monfort, P., and Mostajir, P.: Interactions of ultraviolet-B radiation, mixing, and biological activity on photobleaching of 61 natural chromophoric dissolved organic matter: a mesocosm study, Limnol. Oceanogr., 45, 278-291, 2000.

Whitson, I. R., Abboud, S., Prepas, E. E., and Chanasyk, D. S.: Trends in dissolved phosphorous in Gray Luvisol soil profiles after harvest, Can. J. Soil Sci., 85, 89-101, 2005.

Wickland, K. P., Neff, J. C., and Aiken, G. R.: Dissolved organic carbon in Alaskan Boreal Forest: sources, chemical characteristics, and biodegradability, Ecosystems, 10, 1323-1340, 2007.

Winkler, G., Leclerc, V., Sirois, P., Archambault, P., and Bérubé, P.: Short-term impact of forest harvesting on water quality and zooplankton communities in oligotrophic headwater lakes of the eastern Canadian Boreal Shield, Boreal Environ. Res., 14, 323 337, 2009.

Zsolnay, A., Baigar, E., Jimenez, M., Steinweg, B., and Saccomandi, F.: Differentiating with fluorescence spectroscopy the sources of dissolved organic matter in soils subjected to drying, Chemosphere, 38, 45-50, 1999. 